\title{
やましそとおほやましその雜種に就て
}

\author{
永 夰 威 三 即
}

一. 緒言

中ましそ(Uosla japonica，Uaxim.)は本邦に自生する唇形科植物にして明治二十二年

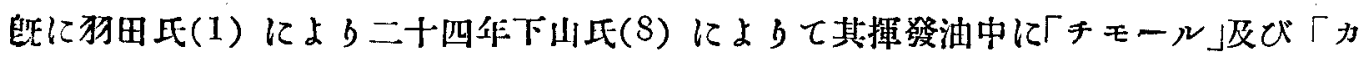
ハブァクロール」の含有せらるつてと檢證せられれる、而して歐洲大践に際し本邦に

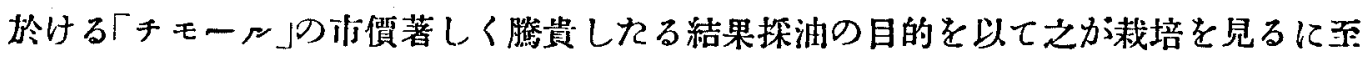
れら、現在に於てはやせしそは本䢀產にして「チモール探取原料としての陮一のもの そるの觀あり。

おほやましそはやましそに粨似せる植物にして近時中井猛之進氏は之を新種之認め Uosla Hadeii, Nalaai. と命名せられれる、蓋しての植物は中ましその如く「チモール， を念有せずしてその同素體にして非結晶性なる「カルブァクロール」のみを含存するが

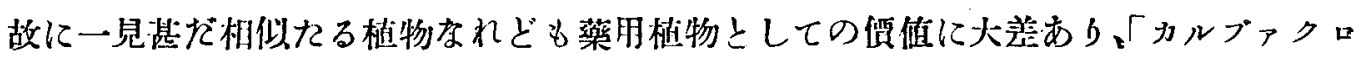
ールは薬用として現時殆んど其㨫倠を認めら水ず。

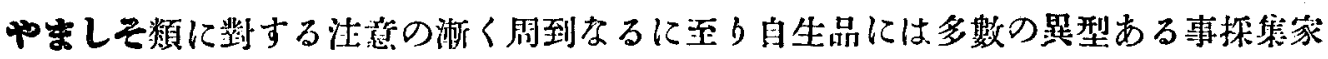

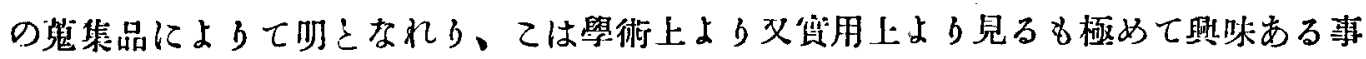
實にして從來二三の研笔者がやましそに「チモール」の存在を證朋し得九る場合と得ざ

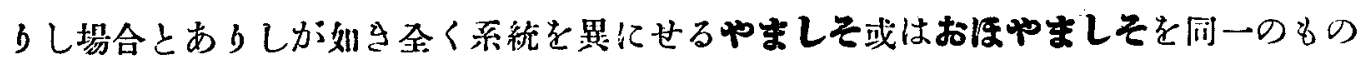

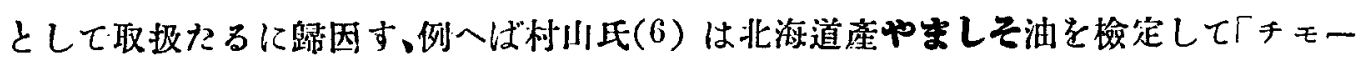

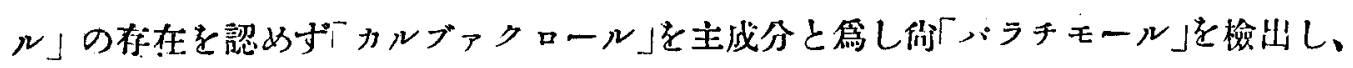
其後村山、奈良雨氏(7) は「アルフアピネーン」の存在を检叫せら、古川、豈攞雨氏

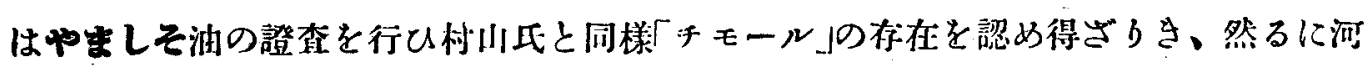

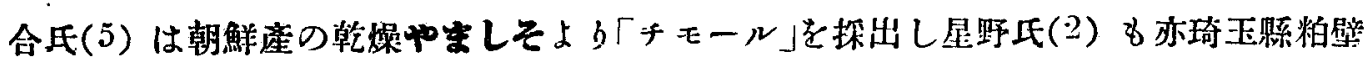




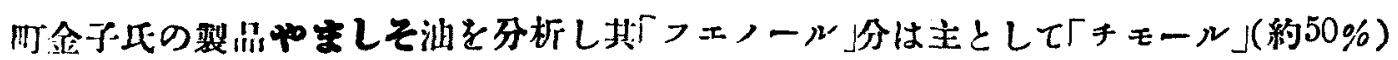
より成ら「かルブァクロール」を撿登し得ず、攸其他「ガンマシモール」以外の主なる「ラ ルベン」として「タービネン」等を證し永たり、刚米、渥美兩氏(3.4.)は同じく粕壁町 產の精油に就て研笁し「チモール」の存在を證せり。

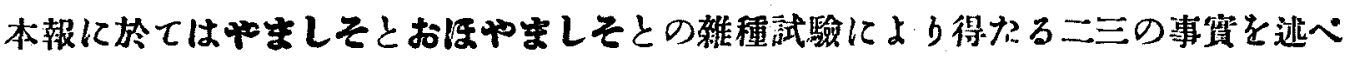
ん交。

\section{二. 供試品及び其形態}

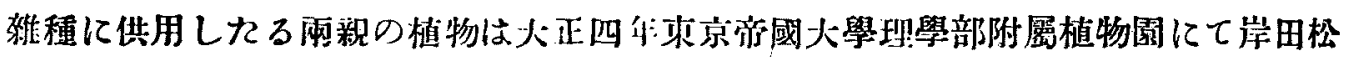

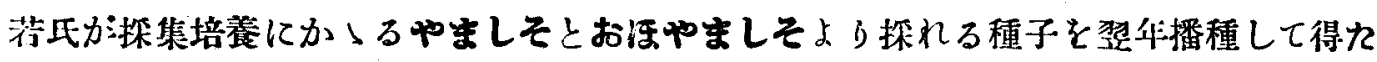
る多數の植物中より撰擇せり。

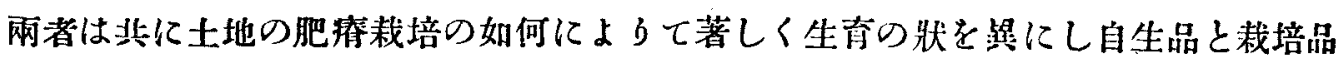
とは一見別種の如さ觀を示するのあり、從つて記载によらてのみ兩者を區別せんとす る川1占は其生育の狀况を考慮する必要あり。

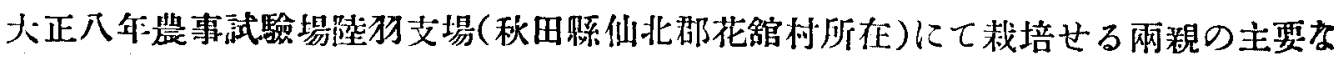
る形態上の差異を訅すれば次の如し。

\begin{tabular}{|c|c|c|}
\hline & かましそ & おほやましそ \\
\hline 经 & $\begin{array}{l}\text { 方形にて毛茸あb } \\
\text { 主经の長さ } 30-40 \mathrm{~cm}\end{array}$ & $\begin{array}{l}\text { 同 上 } \\
\text { 主䒱の長さ } 30-50 \mathrm{~cm} \text {. }\end{array}$ \\
\hline 枝 & 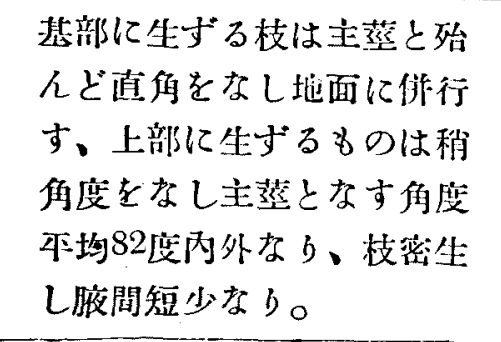 & 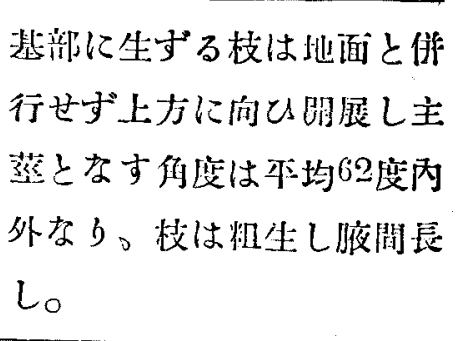 \\
\hline 花總 & $\begin{array}{l}\text { 花は骂一腋間に着生し主蓝 } \\
\text { 及び枝の先端部に於て花總 } \\
\text { を形成す。 }\end{array}$ & $\begin{array}{l}\text { 花總はやましそに比して棌 } \\
\text { 長大なら. }\end{array}$ \\
\hline 藮形狀 & 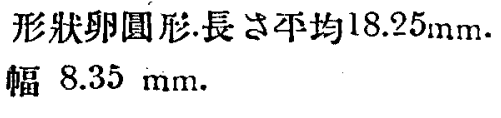 & 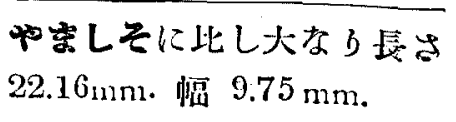 \\
\hline
\end{tabular}




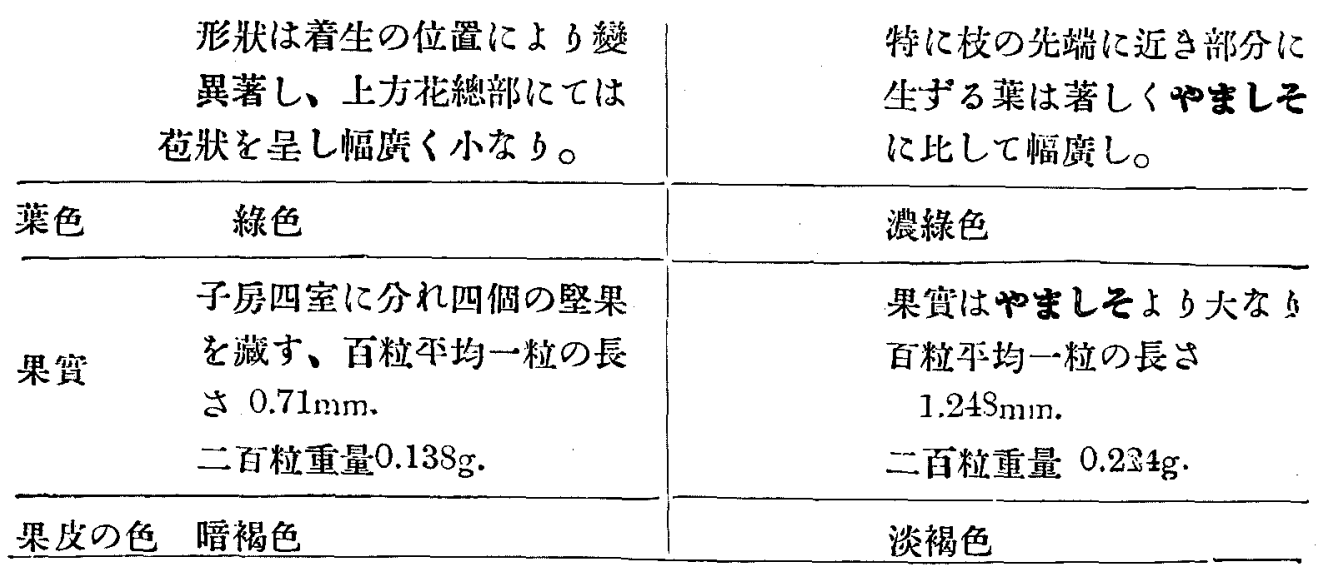

之を要するにおほやましそはやましそに比して菎長、葉、花總、果筫等㫮大にして 葉綠又漕厚、生育一㻺旺盛なるものとす。

\section{三 雜 種 $\left(\mathrm{F}_{3}\right)$ の 形 態}

大正五年交配によるて得九るF $F_{1}$ 四十九株は形態お医やましそに類似す、殊に葉の形 狀、也相、花總の形態、莖長等に於ておほ中ましそと同樣なる唯枝榴分岐の性狀はや ましそに類似し地面に併行して生ず、F、湘物は完圣に絬賀し多數の種子を生ず、乙れ

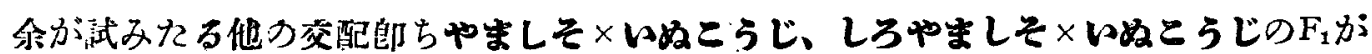
完全不結貸なると火溃る所な少。

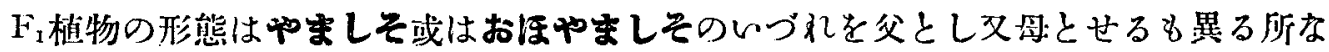
Lo

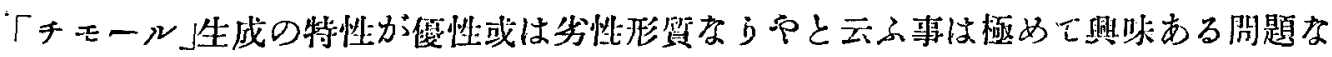
れども多数の材料を得べからざるにより末だ沈定的解氿を得ず。

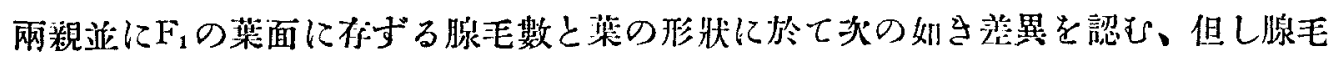

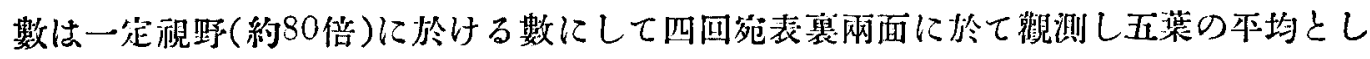

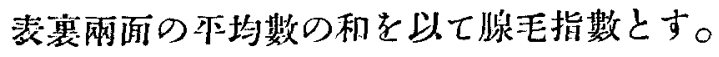

\section{第一表腺毛數の變基}

\begin{tabular}{|c|c|c|c|}
\hline & やむしそ & 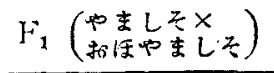 & 出ほやみしそ \\
\hline 非面㟫毛數 & 5.35 & 9.05 & 9.1 \\
\hline 袞面腺毛数 & 8.20 & 6.9 & 10.25 \\
\hline
\end{tabular}




\begin{tabular}{|c|c|c|}
\hline 腺 毛 指 數 & 13.55 & 15.95 \\
\hline 葉 長 $(\mathrm{cm})$ & 2.14 & 2.65 \\
\hline 葉 幅 $(\mathrm{cm})$ & 0.9 & 1.36 \\
\hline
\end{tabular}

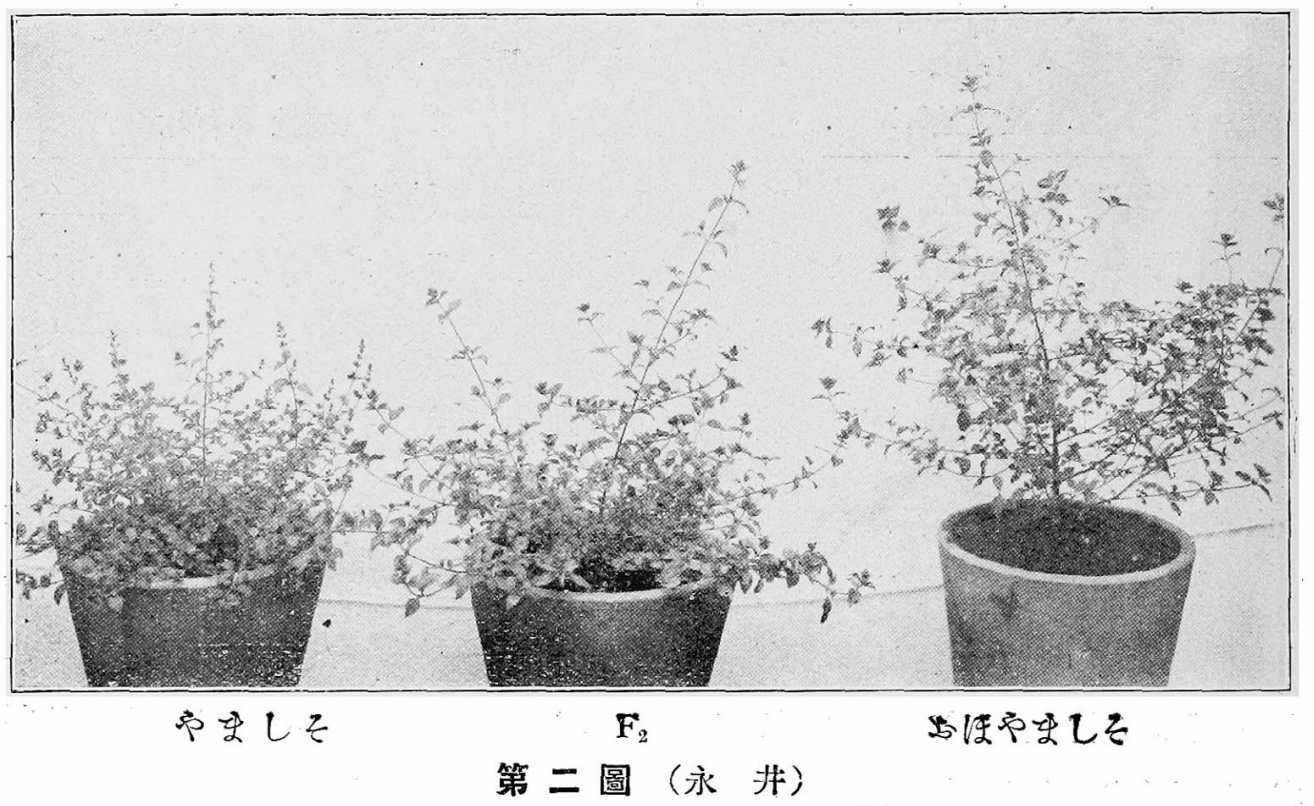

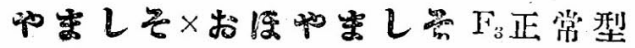

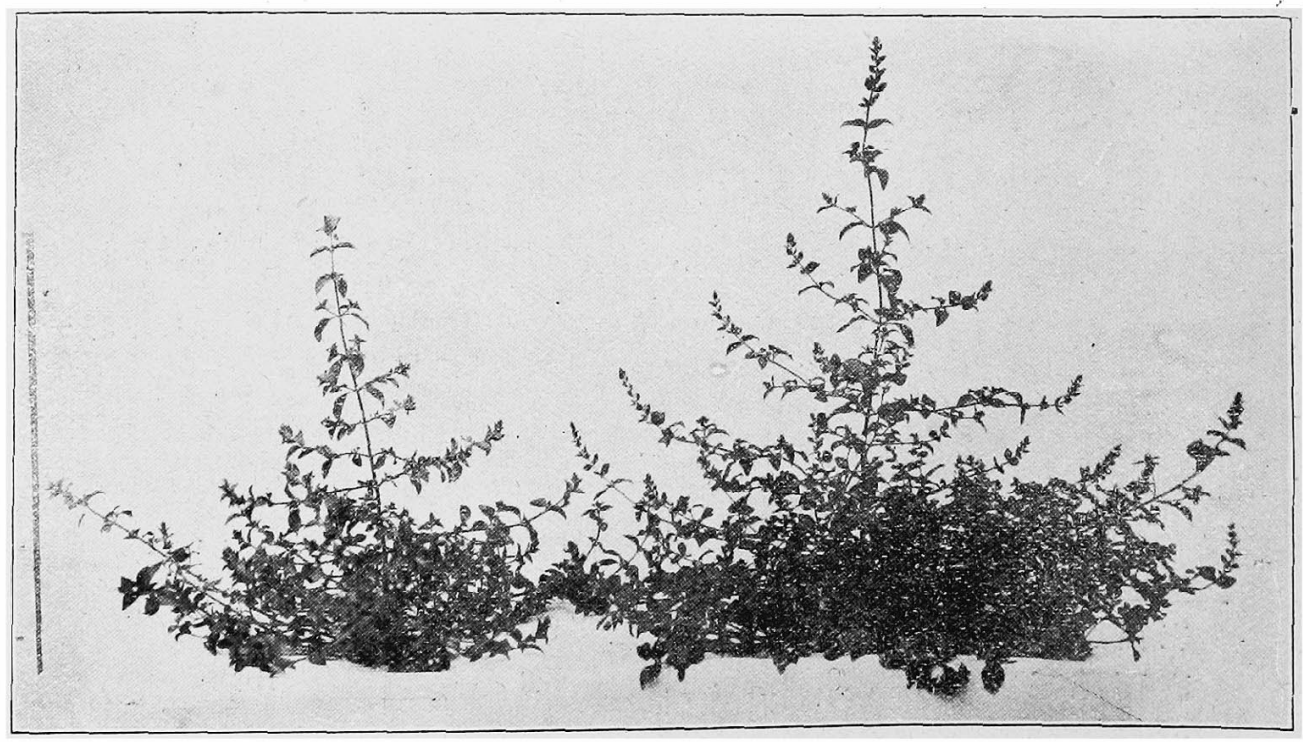




\section{四. 雜種 $\mathrm{F}_{2}$ 及其以後}

$F_{2}$ に於ては極队て多數す黑型を分離せb、乙れ别すれば (1) 正常型 (2) 矮型及 び (3) 中間型とするを得れども正常型中には简多數の翼型を含む、然して其間に韭然

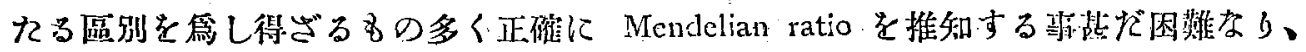
大別すれば

算三圖（永北）

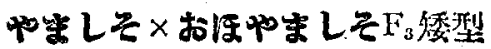

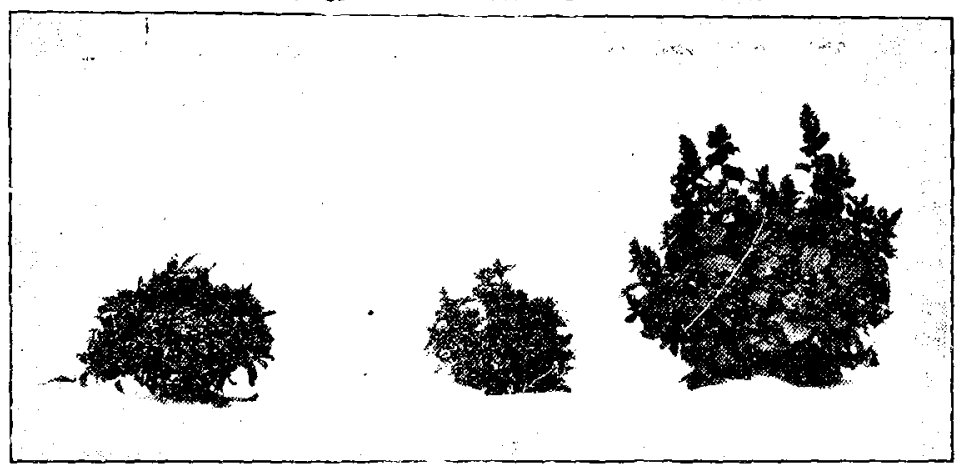

第四圖 (永 非)

花總の形状 (1/4)

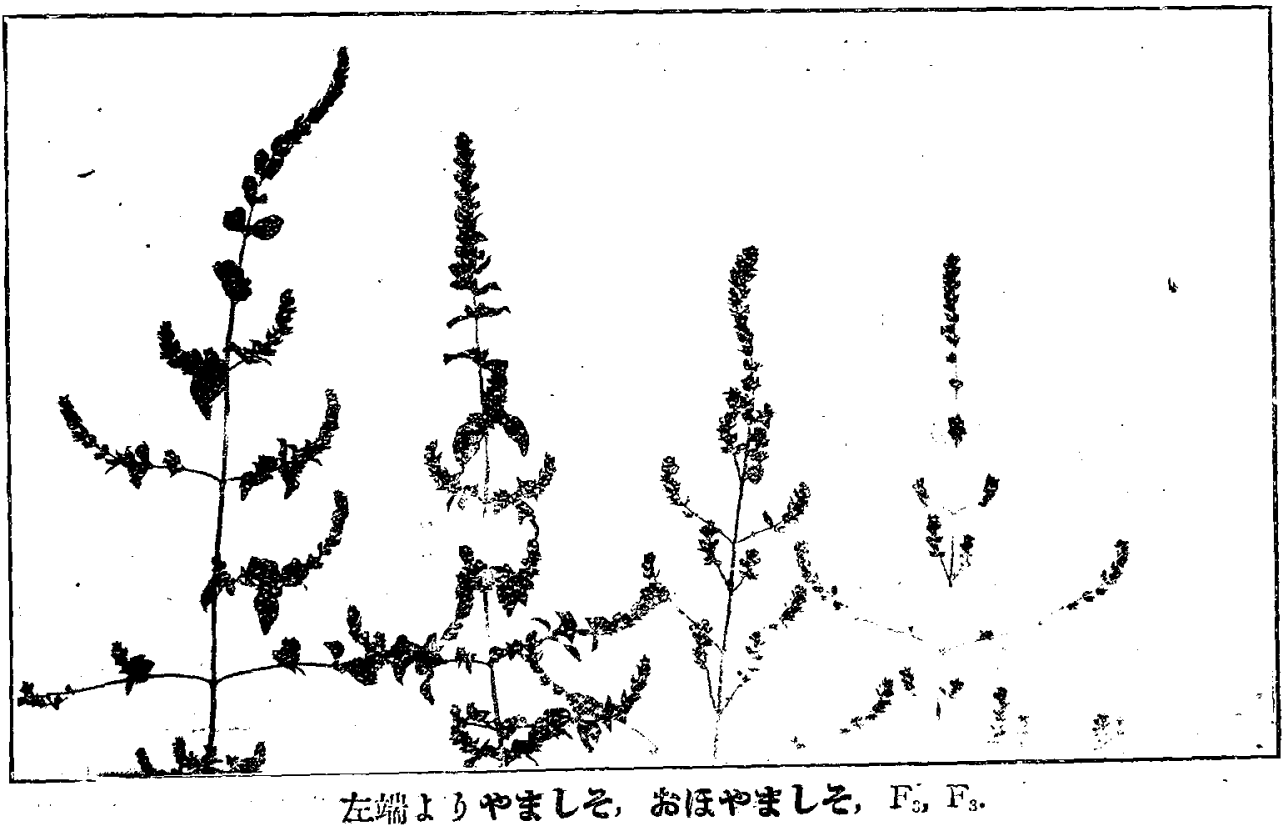

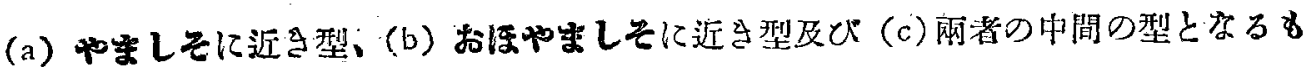




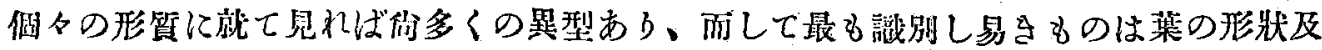
び線色の浱淡、枝榴分肢、着生の性狀及び花總の形狀とす、正常型に屬するるのは䒯 長 $30-50 \mathrm{~cm}$ 算せり。(笏二门至第六圖參照)

第五圖（永井）

闹上 $F_{3}$ 花總の短なる尚の $(1 / 4)$

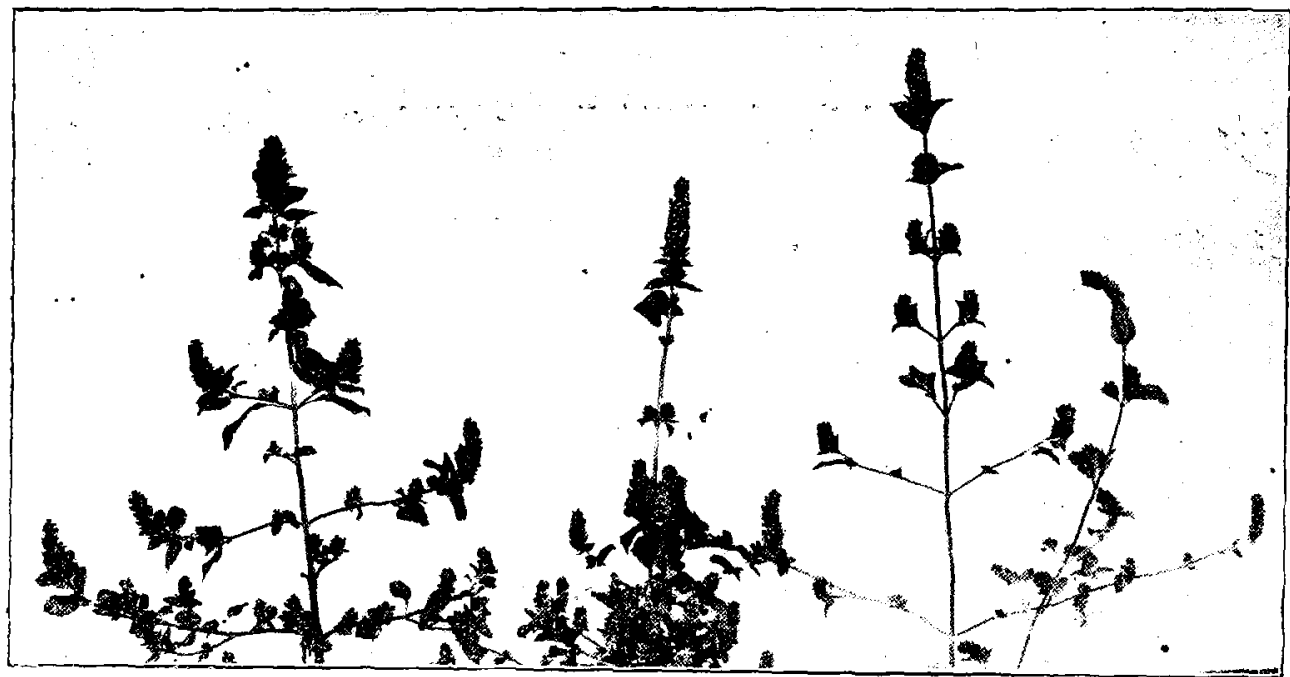

第六圖（永来）

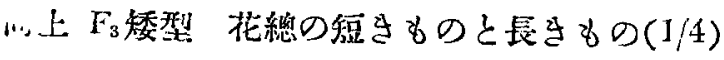

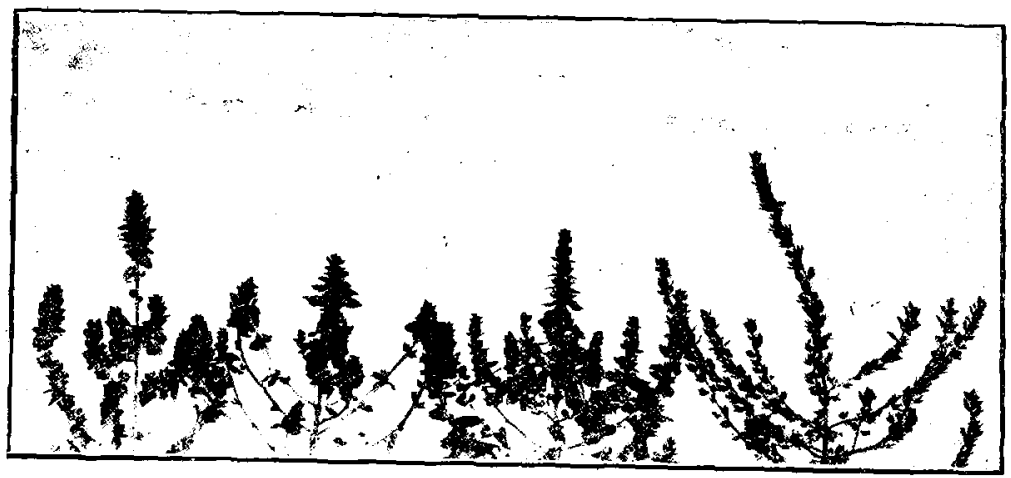

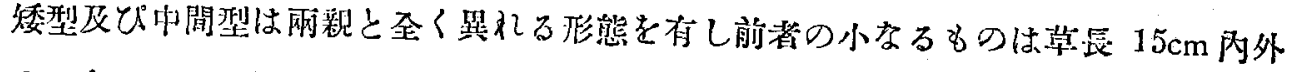

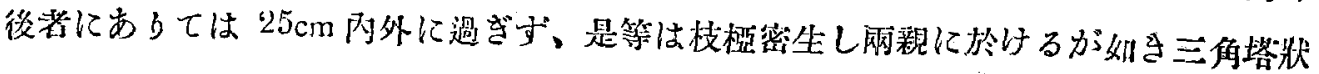
を是せずして栁狀を呈す。

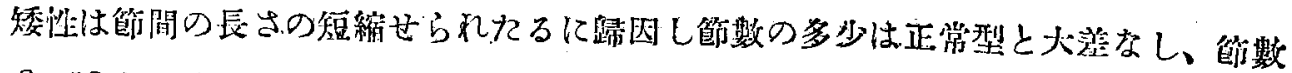

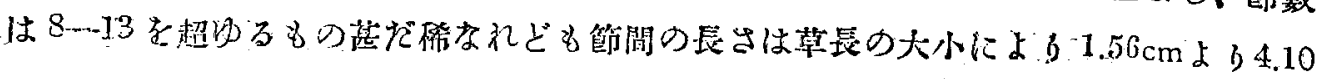


cm.l至石，

今頂部よb數へて五個の節間の長さの平均と全草長との相關禁哭を矮型を分離せる $\mathbf{F}_{3}$ の或る一系に就て調査せる結果を示せば第二表の如し。

\section{第二表 節間の長さと草長〉の相關變異}

篩 間 $の$ 長 $(\mathrm{cm})$

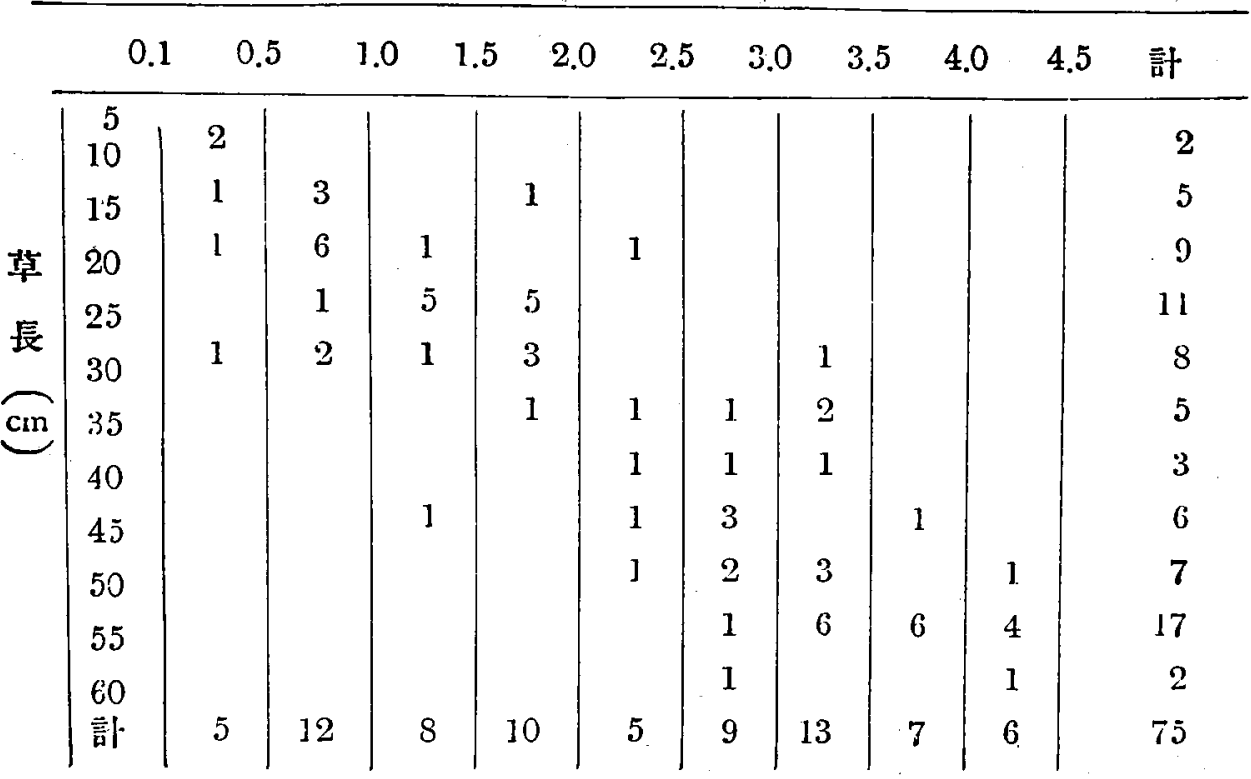

節間の辰 $M=2.23 \vec{\imath} \pm 0.253$

$$
\sigma= \pm 1.225 \pm 0.183
$$

草 長 $M=34.30 \pm 3.061$

$$
\begin{aligned}
& \sigma= \pm 14.890 \pm 1.183 \\
& \gamma=+.871 \pm 0.028
\end{aligned}
$$

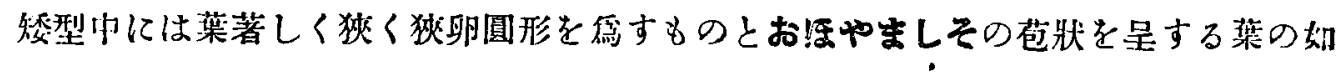

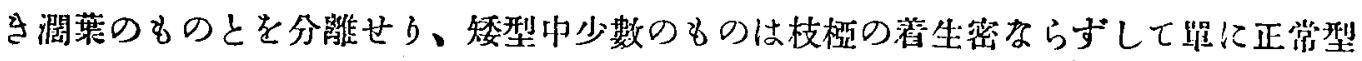
者極端に矮少ならしぬたるが如さものあり。

\begin{tabular}{|c|c|c|c|c|c|c|}
\hline$F_{2}$ 系統番咙 & 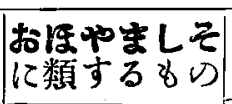 & $\begin{array}{l}\text { や宝しそに } \\
\text { 類するおの }\end{array}$ & 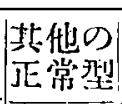 & 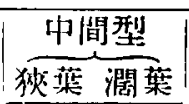 & 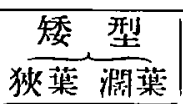 & 計 \\
\hline$(\geq 8-1$ & 50 & 14 & 14 & 2 & 4 & 91 \\
\hline
\end{tabular}

$\mathrm{F}_{2}$ 亿於ける各型の數は第三表に示すが如し。

第三表 F.に於ける分䧺型 


\begin{tabular}{|c|c|c|c|c|c|c|c|c|}
\hline $18-2(J A \times H-A)$ & 175 & 55 & 18 & $\longrightarrow$ & 15 & - & 18 & 281 \\
\hline $18-5(\mathrm{H}-\mathrm{II} \times \mathrm{J}-\mathrm{I}-2)$ & 222 & 69 & - & - & 12 & - & - & 303 \\
\hline $18-6($ & 46 & 12 & 16 & 4 & 4 & 1 & 4 & 87 \\
\hline $18-7(J-1 \times H-I I-2)$ & 63 & 21 & 1 & - & 2 & - & 5 & 92 \\
\hline $18-8(J-1 \times H-I I-1)$ & 31 & 6 & 9 & 2 & 1 & 1 & 5 & 55 \\
\hline $18-9(\mathrm{~J}-\mathrm{L} \times \mathrm{H}-\mathrm{II}-2)$ & 63 & 13 & 2 & - & 6 & 3 & 3 & 95 \\
\hline $18-10(\ldots \prime \prime)$ & 91 & 16 & - & 一 & 一 & - & - & \\
\hline $18-12(1-1 \times J-1 I-1)$ & 17 & 6 & 3 & 一 & 1 & 1 & 1 & \\
\hline $18-14(J-I I \times H-1-4)$ & 30 & 20 & 21 & - & 7 & 9 & 3 & \\
\hline $18-17(\mathrm{~J}-1 \times \mathrm{H}-\mathrm{II}-1)$ & 115 & 35 & 3 & 2 & 5 & 5 & 9 & 17 \\
\hline $18-1 S($ & 195 & 42 & 4 & - & 15 & 6 & 8 & 2 \\
\hline $18-20(\mathrm{~J}-\mathrm{II} \times \mathrm{H}-\mathrm{III})$ & $9 \pm$ & 28 & 1 & 1 & 5 & 2 & 8 & 1 \\
\hline $18-21(\mathrm{~J}-\mathrm{III} \times \mathrm{H}-\mathrm{II})$ & 106 & 19 & - & 1 & 12 & 1 & 13 & \\
\hline 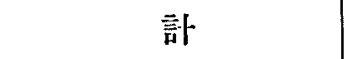 & 1298 & 356 & 92 & 12 & 89 & 32 & 81 & 1930 \\
\hline
\end{tabular}

總計 1960 株のF 2 亿就て矮型は然らざるものに對して約 $15: 1$ の比を鴒せり。 正橆型と中間型

鿓 噞 数 1848 婑 型

推 算 數 望 1838.43 113 122.56 $+9.57$ $-9.56$

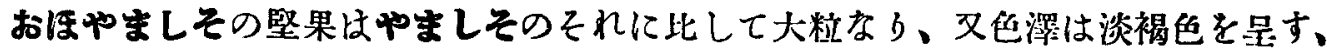
此等は兩種を識別する特徵の一な る $\mathrm{F}_{1}$ 植物に生ずる堅果は色相に於てお活かましそに 類似すと踓る其大さは稍や小な b、F $F_{2}$ に於ける分離は粒大に就さ五階級を設け標準に 比较して分類を試みれるに次の如さ結果を得てり。

$\begin{array}{rcccccc}\text { 比大の階級 } & \text { I } & \text { II } & \text { III } & \text { IV } & \text { V } & \text { 計 } \\ 18-1 F_{2} \text { 個體數 } & 25 & \text { : } & 13 & 31 & 2 & 91\end{array}$

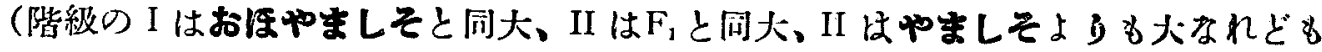

F1より小なるもの、IVはがしそと同大、Vは中ましそよりる小なるすの)

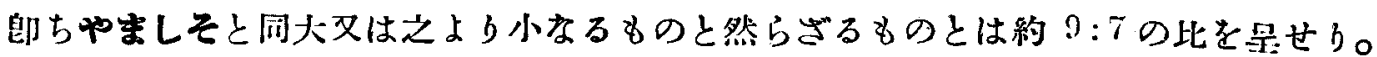

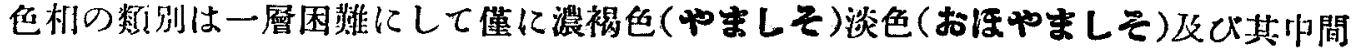

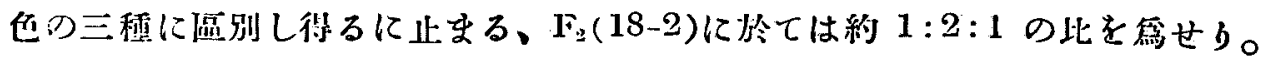

濃褐色中閐色淡褐色計

垈 驗 數 $47 \quad 134 \quad$ \&3 $\quad 264$




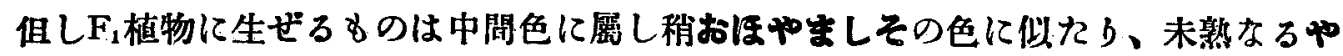
ましその果實は乾燥後淡褐色を呈し本爽の䙮色を咞せず。

大正五年播種しれる多數のややましその筫生中一株の一部に白班葉を生ぜるもの有 しがそと綠葉なるおほ中ましそとの雑種に就て白斑葉の遺停的性狀を見るに白斑葉を 有する枝上に生ぜる花の花粉を配しれる雜種のF して白班ある募を有する花に綠葉おほやましその花粉を配しれる $F_{2}$ に於てる少數の白斑葉を生ぜウ、白斑葉ある $F_{1}$ 植物の白斑葉ある枝に生ぜる種子を 探り播種せるに子葉全白 (44)全綠(49)及び斑葉(14)の三種を生じ全白なるものは暫時 にして死減せら、てれに依て見れば他の植物に於けるが如さ母性遺傅を表するのつ如 L。

やましそ及びおほやましその葉面には腺毛と非腺毛とを生し、前者は揮發洫を分泌 するが故に橙黄弁の光輝ある細點を表す。

探油率の多少は從つて腺毛の多少と關係ある可く腺毛多さるの程探油率む大ならざる 可からず。

脉毛の分有は同一葉にありては裹面に多く表面に少く、同一葉面にありては邊緣部 に多く中央部に於て少し、葉の着生の位置によりては殆んど大美あるを見ずと雖も標

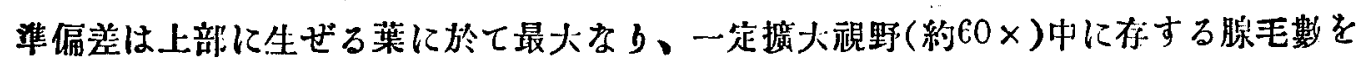
各葉表稟雨面に於て二回宛合計四回調查し、葉は之を植物の上小下の三部よb探り一 株につ马總計十二回の觀湘を行ひ表裏兩面の本均價の合計を以て其個體の腺王指数と 爫し、F:に於ける異型に就て其差異を檢せるに头に示すが姆さ結果を得なり。

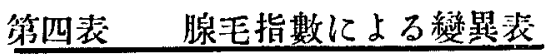

個體の種䉼

腺毛 指 数

ఖましそ(J-23)

お师ましそ

$F_{1}$

$F_{2}$ やほやましそに類する型

$F_{2}$ 兩親の中間に屬する型

1

\begin{tabular}{r|r|r|r|}
20 & 25 & 30 \\
- & - & 3 \\
- & - & - \\
- & - & 1 & \\
- & 11 & 18 \\
- & 1 & 3
\end{tabular}

\begin{tabular}{r|r|r|r}
35 & 40 & 45 & 計 \\
2 & - & - & 5 \\
2 & 1 & - & 3 \\
- & - & - & 1 \\
11 & 8 & 2 & 50 \\
2 & 3 & - & 9
\end{tabular}


$\mathrm{F}_{2}$ メ゚ましそに類する型

$F_{2}$ 矮 型

$\mathrm{F}_{2}$ 中闑 型

部

$$
\begin{array}{|r|r|r|r|r|r|r}
- & 1 & 2 & 6 & 3 & 1 & 13 \\
3 & - & 3 & 3 & 1 & - & 10 \\
-3 & 1 & - & - & 1 & 1 & 3 \\
14 & 30 & 26 & 17 & 4 & 94
\end{array}
$$

（储考 $\mathrm{F}_{2}$ 及び其兩漞は大正比年栽培品、 $\mathrm{F}_{1}$ は大正六年栽培品による） 腺毛指數の葉の位置による美異を $\mathrm{F}_{3}$ 植物 19336 系の和均に就て示せば次の如し。

\begin{tabular}{lcccc} 
& & 上位 & 中 位 & 下 位 \\
葉 & 表 面 & 13.416 & 13.028 & 15.556 \\
葉 & 襄 面 & 17.525 & 16.194 & 17.305 \\
\cline { 2 - 5 } 計 (指 & 數) & 30.941 & 29.222 & 30.861
\end{tabular}

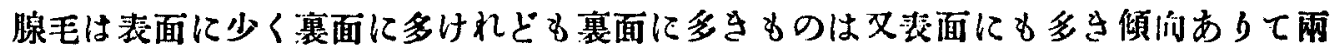
者の相關係數 $(\gamma)$ は +0.76 算せり。

\begin{tabular}{|c|c|c|c|}
\hline & 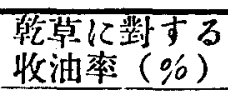 & $\begin{array}{l}\text { 總フェ： } \\
\mu(\%)\end{array}$ & Fモール \\
\hline 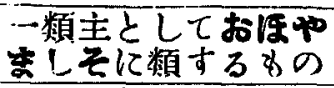 & 0.653 & 33.90 & 31.08 \\
\hline $\begin{array}{l}\text { 類主としてゃま } \\
\text { そに類するわの }\end{array}$ & 0.491 & 42.89 & $\$ 7.00$ \\
\hline 三頑矮型及び中間型 & 0.534 & 35.3 .3 & 30.33 \\
\hline 均 & 0.559 & 37.37 & 32.80 \\
\hline
\end{tabular}

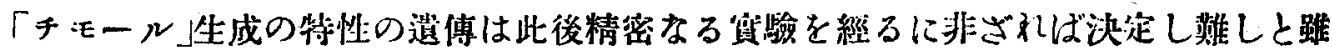

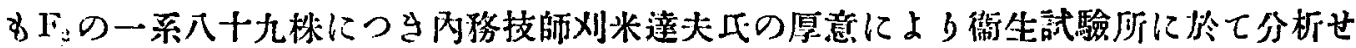
られれる結果を示せば次の如し。

第五表 F植物の分析表

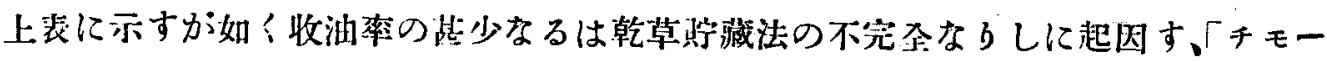
ル」含有量の定量的決定には多量の乾草を必要とするが故に之の如さ小辈を以て得た る結果は蓋し多大の信を置さ難さすのなら。

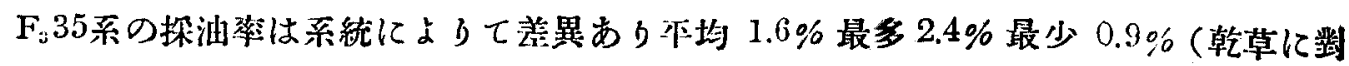
し)を算せり、收楼に先ち種子用として保有しにる各系十株の葉に就て調查しれる腺毛

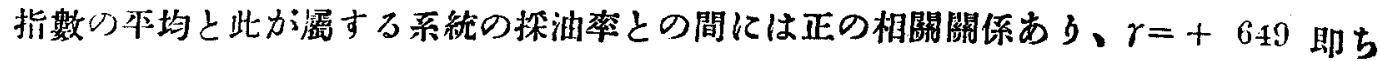


腺毛指數大なる系統の探油率亦大なる傾向明暸なり。

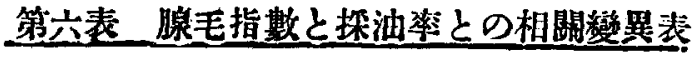

\section{腺毛 指 敷}

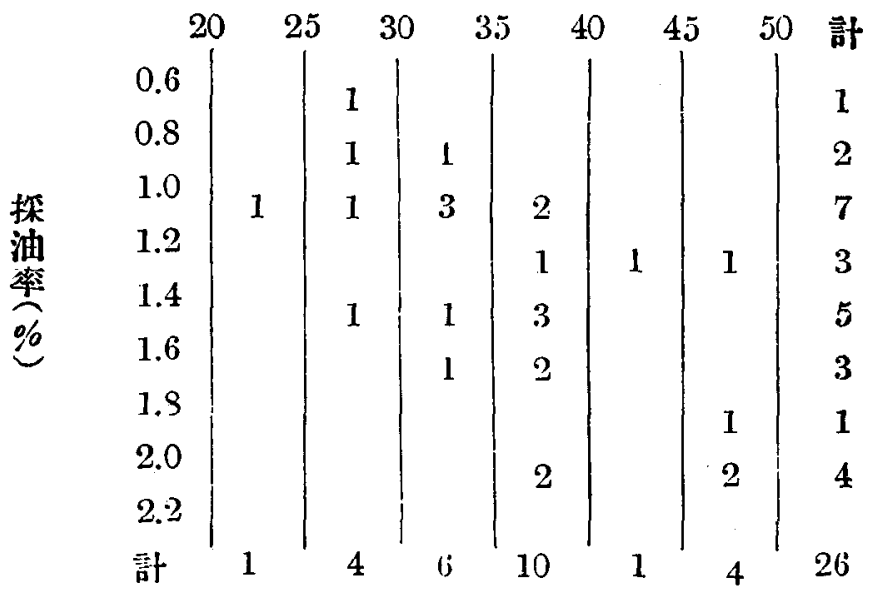

腺毛指數 $\mathrm{M}=: \% 6.3 \pm 1.305$

同

$$
\sigma= \pm 6.521 \pm 0.185
$$

探 油揫 $\mathrm{M}=1.6: \pm 0.08$

同

$$
\sigma= \pm 0.412 \pm 0.058
$$

$$
\gamma=+.649 \pm 0.012
$$

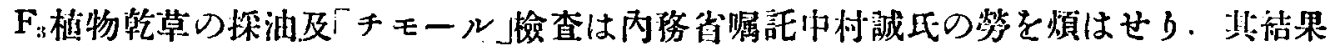

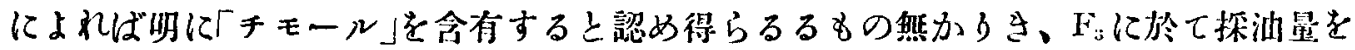

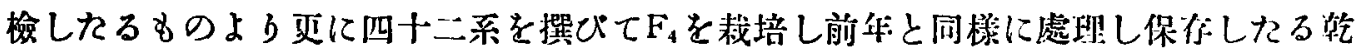
草に就さ大正十年一月蒸溜檢定を試み九る十四系中には明に「モール」の結晶を得れ

\begin{tabular}{|c|c|c|c|c|c|}
\hline$F_{4}$ 藿 & 號 & $F_{3}$ 楼 號 & $F_{::}$の探汕藮 $(\%)$ & $F_{1}$ の探油率（\%) & $\begin{array}{l}\text { 蒸溜油5cc.に對す } \\
\text { る䉼チモール(gr.) }\end{array}$ \\
\hline \multicolumn{2}{|c|}{$H A \times J-A 20-33$ ? } & \multirow{2}{*}{$\begin{array}{l}19-12 \\
\quad \text { il }\end{array}$} & 1.4 & 1.46 & 0.083 \\
\hline$" \prime$ & $32\}$ & & 1.4 & 1.50 & - \\
\hline$\prime \prime$ & 52 & $12-20$ & ? & 1.49 & - \\
\hline$" \prime$ & 2 & $19-1$ & 2.0 & 1.60 & 一 \\
\hline
\end{tabular}
るるの四系ありれる、即ち炏表に示すが如し。

\section{第七悲 探泊率並粗「チーモル、念㮅星}




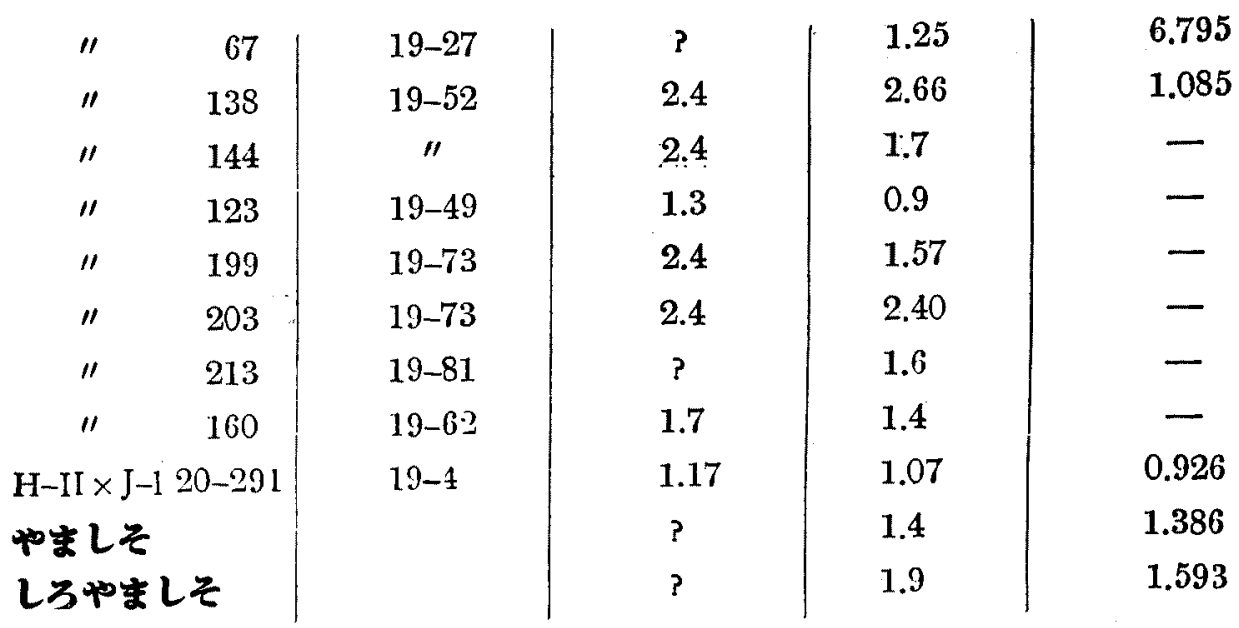

「チモール」結晶を得てる系統の植物は其形態やましそに類せず反つておほやましそ

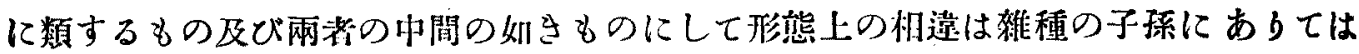
「チモール」の有無を推察するの根據を煘さずと云及事孛知れり。

既に逨べれるが如く $F_{2}$ 亿於て分離したる裂型植物の數は略 $15: 1$ の少性に相當せb、 $\mathrm{F}_{3}$ の結果を見るに左の如し。

實驗教
（a）矮型を分躴せざろし正常型
（b）矮型を分蓶せし正常型
(c) 中 間 型

推算數

美

40

36.40

3.6

36

$2\}$

41.60

3.6

$78 \quad 78.0$

矮型を分離せし 36 系中には左の如さ系統あり。
(a) 矮型を $15: 1$ に分離せしもの
(b) 矮型を $15: 1$ に近さ比に分離せしもの
（c）矮型を $3: 1$ に分離せしもの
（d）分離の比兩者の略中間にあるもの

\begin{tabular}{cc}
$\begin{array}{c}12 \\
2\end{array}$ & 20.8 \\
\hline 36. & 36.
\end{tabular}

(a)と(b)，(c)と(d) とを合計して推算數と此較すれば略矮型が $15: 1$ の少性として 行動すべもものるを證す、然るに矮型のF ても同粯充分筫驗上の誤美なからしめん事を期しれるにる拘らず杘逆的正常型の出現 


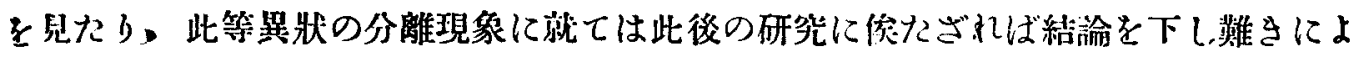
り詳訬せず。

本試驗の逐行に際し柴旧桂太氏、刚米達夫氏、中村㖅氏、崖田松若氏及び塚本定五 郎氏の援助に與りてる事多し、謹んで威謝の党を表す。

$$
\text { 大正十年九月 }
$$

引用㸉文

1. 狗田㿽吉 藥學雥誌 92 號718.(1889).

2. 星野耕三 工業化學雜誌 257 號 557 (1919).

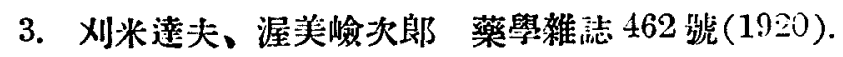

4. 同同官垠(大正无作七月二十六日).

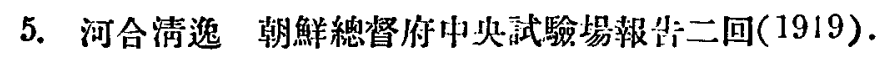

6. 村川義温 藥學雜誌 333 號 1185 (1911).

7. 村川義温、奈良義次 藥學雄俧 363 號 457 .

8. 下山顺一郎 蔡學雜誌 1 C7號 (1891).

9. 古川清治、富澤善炏郎 工業化學稚誌 255躆 382(1919). 